\title{
Pinturas murales de la casa de Ariadna (Pompeya, Italia): un estudio multidisciplinar de su estado actual enfocado a una futura restauración y conservación preventiva
}

\section{Ariadne 's house (Pompeii, Italy) wall paintings: A multidisciplinary study of its present state focused on a future restoration and preventive conservation}

\author{
M. C. Pérez $(*)$, F. J. García-Diego ${ }^{(* *, * * *)}$, P. Merello(*,**), P. D’Antoni(*), A. Fernández-Navajas(**), \\ A. Ribera i Lacomba $(* * * *)$, L. Ferrazza $(*)$, J. Pérez-Miralles $(*, * * * * *)$, J. L. Baró(**), P. Merce ${ }^{(*)}$, \\ H. D'Antoni(******), J. Curiel-Esparza $(* *, * * *)$
}

Recepción / Received: 22-III-12

Aceptación / Accepted: 28-IX-12

Publicado online / Online publishing: 26-X-12

\section{RESUMEN}

Este trabajo desarrolla un estudio multidisciplinar sobre el actual estado de conservación de la casa de Ariadna (Pompeya, Italia), domus de gran valor arqueológico. El objetivo es aumentar el conocimiento del estado actual de conservación de la casa para la discusión de una futura restauración. Para ello se realizaron estudios ambientales, mediciones de radiación electromagnética, estudio de materiales y un estudio fotográfico. Los estudios revelaron que los tejados que cubrían las salas analizadas estaban originando unas condiciones climatológicas adversas que se traducían en un grave daño para la conservación de las pinturas murales. Entre 2009-2010 se cambiaron las cubiertas y los estudios ambientales fueron repetidos. Los estudios de materiales demostraron que las pinturas coinciden en ejecución y composición con las señaladas por

\section{ABSTRACT}

This paper deals with the development of a multidisciplinary study on the current state of conservation of Ariadne's house (Pompeii, Italy), a domus of great archaeological value. The aim of this study is to undertake the preventive conservation actions required and increase the knowledge about its conservation and to generate discussions and points of view for a future restoration. Environmental studies, electromagnetic radiation measurements, study of materials and a photographical study were carried out. Those studies revealed that the rooftops covering the analyzed rooms resulting in adverse weather conditions causing grave damage to the conservation of the wall paintings. Thus, between 2009-2010 the rooftops were changed and new environmental studies were conducted. Studies of materials showed that the paintings match in execution

\footnotetext{
(*) Instituto Valenciano de Conservación y Restauración de Bienes Culturales (IVC+R) (Castellón, España).

(**) Universidad Politécnica de Valencia (Valencia, España).

(***) Unidad Asociada ICMM- CSIC/UPV.Universidad Politécnica de Valencia (Valencia, España).

(****) Ayuntamiento de Valencia (Valencia, España).

$(* * * * *)$ Exma. Diputación de Castellón (SCRC) (Castellón, España).

$(* * * * * *)$ NASA Ames Research Center, Moffett Field (California, USA).
} 
otros autores. Las sales procedentes de morteros modernos de anteriores restauraciones afectaban a las pinturas, también se describe una fina capa superficial de tonalidad grisácea procedente de contaminantes ambientales.

Palabras clave: Pompeya; conservación preventiva; materiales; monitorización ambiental; fotografía.

\section{INTRODUCCIÓN}

La casa de Ariadna o "dei Capitelli colorati", se encuentra en el "Regio" VII, ínsula 4 (Pompeya, Italia), en una ubicación privilegiada en el centro de la ciudad, a menos de 100 metros del foro. Con $1.700 \mathrm{~m}^{2}$, es una de las domus señoriales más grandes de la arquitectura pompeyana (1).

La casa de Ariadna fue excavada entre 1832 y 1835 y durante el siglo XIX fue una de las casas pompeyanas más famosas y visitadas, cayendo posteriormente en el olvido (2).

En este trabajo vamos a estudiar las pinturas murales de las habitaciones 1, 2, 3 y 4 (Figura 1). Estas cuatro salas se encuentran decoradas con pinturas murales desde el primer al cuarto estilo pompeyano (1). and composition with those reported by other authors. The salts from modern mortars from previous restorations were affecting frescoes, also it is described a thin grayish surface layer from environmental contaminants.

Keywords: Pompeii; preventive conservation; materials; environmental monitoring; photography.

\section{INTRODUCTION}

Ariadne's House or "dei Capitelli Colorati", is located in the "Regio" VII, insula 4 (Pompeii, Italy), in a privileged location at the center of the city, less than 100 meters from the forum. With $1700 \mathrm{~m} 2$ it is one of the biggest stately domus of the private Pompeian architecture (1).

Ariadne's House was excavated between 1832 and 1835 and during the 19th century it was one of the most famous and visited Pompeian houses, later to sink into oblivion afterwards (2).

The rooms considered in this work are: numbers 1, 2, 3 and 4 (Figure 1). These four rooms are decorated with murals from the first to the fourth Pompeian style (1).

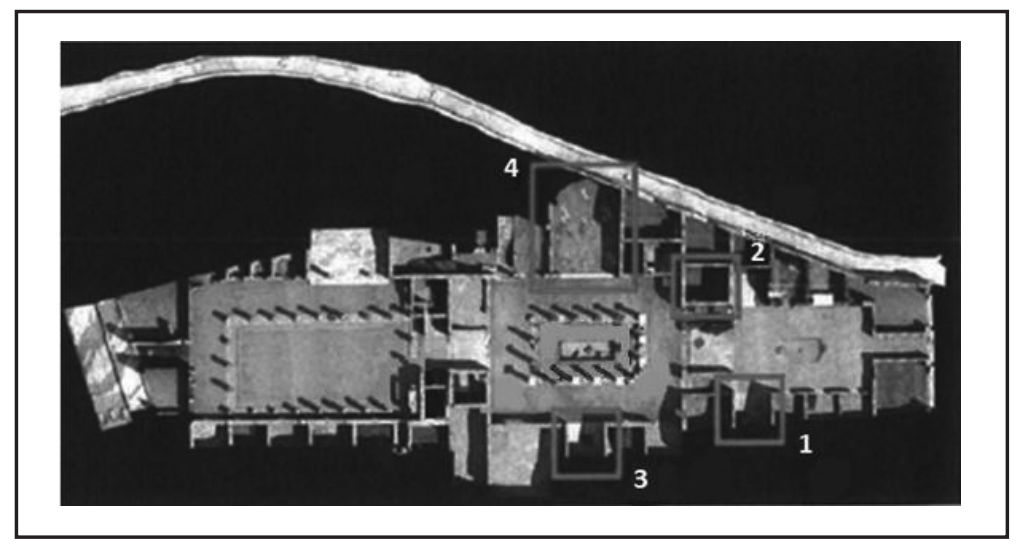

Figura 1. Planta de la casa de Ariadna. Este plano fue realizado por el Ayuntamiento de Valencia. Figure 1. Floor of Ariadne's house. This map was made by the City Council of Valencia.

Durante los años 70 se instalaron unas cubiertas consistentes en una estructura metálica sosteniendo láminas de policarbonato transparente, estos tejados fueron instalados en tres habitaciones de la casa (salas 1, 2 y 3 de la Figura 1). En 2010, estas cubiertas transparentes fueron cambiadas por un techo aislado no transparente. La sala 4 (Figura 1) se encuentra parcialmente cubierta de teja.

En la sala 3, se encuentra un mosaico emplazado como emblema central de la planta. El mosaico, de tradición helenística con unas dimensiones de $84 \mathrm{~cm}$ x $77 \mathrm{~cm}$. Se
During the 70 's a rooftop consisting of a metallic structure holding transparent polycarbonate sheets was installed on three rooms of the house (rooms 1, 2 and 3 of Figure 1). In 2010 the transparent polycarbonate sheets were changed for an isolated non transparent roof. Room 4 (Figure 1) is partially covered with a tile rooftop.

In room 3, there is a mosaic as a central emblem of the plant. The Hellenistic tradition mosaic measures $84 \times 77 \mathrm{~cm}$ squared. It is thought to have been made within the late 
cree que fue realizado entre el siglo II a.C. y el comienzo del siglo primero antes de Cristo. El suelo del resto de la habitación está pavimentado con teselas diferentes, más modernas, que se remontan al siglo primero. El mosaico está cubierto por una caja compuesta por cinco hojas de vidrio de tres milímetros.

Entre 2004 y 2008, un equipo multidisciplinar dirigido por la Sección de Investigación Arqueológica de la ciudad de Valencia, en colaboración con un número de investigadores vinculados a diferentes instituciones científicas, llevaron a cabo 18 sondeos de un extremo a otro de la Casa de Ariadna encontrando restos arqueológicos de todos los períodos de la casa (1).

Los principales problemas que afectan a la casa de Ariadna son la colonización biológica (plantas superiores y animales) y los problemas de lixiviado causados por las lluvias debido a la prolongada ausencia de tejado.

Durante las últimas décadas, se ha desarrollado un creciente interés en todas las áreas de conservación con un enfoque multidisciplinar. La conservación preventiva, como un método de trabajo, tiene como objetivo controlar el estado de conservación de la obra de arte antes de que el deterioro se produzca. En la actualidad, las medidas de conservación preventiva son reconocidas como importantes para salvaguardar el patrimonio cultural (PC, de aquí en adelante), tanto en términos de preservación del PC, como de reducción de costes de las futuras medidas de conservación (3).

En el caso de pinturas murales, el proceso de deterioro se determina por factores tales como las características petrográficas y químicas de los materiales, la presencia de sales minerales y sustancias orgánicas en las superficies, la contaminación del aire, luz solar, temperatura, contenido de agua de la superficie, etc. (4). Por lo tanto, la conservación preventiva requiere el conocimiento de una serie de parámetros relacionados con un sitio específico del PC, incluyendo las condiciones microclimáticas (5), los estudios mineralógicos, la caracterización de la textura, petrofísica y la durabilidad de los morteros. En nuestro caso, al igual que lo documentado en la bibliografía sobre piedra al aire libre ya que resulta difícil encontrar frescos en estas condiciones (6), otros factores biológicos tales como cianobacterias, líquenes, etc. resultaron insignificantes frente a los factores anteriormente mencionados.

El estudio de las técnicas pictóricas utilizadas en el pasado es esencial para la restauración y la conservación preventiva de la obra. Estos estudios son necesarios para comprender los materiales originales y añadidos, presentes tanto en la superficie como dentro de la estratigrafía de la pintura (7-10). Además, los resultados analíticos pueden mejorar el conocimiento general del conservador sobre los 2nd century BC or at the beginning of 1 st BC. The floor of the rest of the room is formed by a different, more modern, paving from the 1st century $A D$. The mosaic is covered with a box composed by five glass sheets of three millimeter.

Between 2004 and 2008, a multidisciplinary team led by the Archaeological Research Section of the City of Valencia, in collaboration with a number of researchers linked to different scientific institutions, carried out 18 surveys from one extreme to another of Ariadne's House finding archeological remains from all of the periods of the house (1).

The main problems affecting Ariadne's house are biological colonization (superior plants and animals) and water problems caused by rains due to the long absence of a roof.

During the last decades, an increasing interest in all areas of conservation with an multidisciplinary approach has been developed. Preventive conservation, as a method of work, aims to control the state of conservation of the artwork before the deterioration occurs. Currently, preventive conservation measures are acknowledged as important for safeguarding cultural heritage ( $\mathrm{CH}$, from here on), both in terms of preserving $\mathrm{CH}$ and also reducing the cost of future conservation measures (3).

In the case of wall paintings, the deterioration process is determined by factors such as petrographical and chemical characteristics of the materials, presence of mineral salts and organic substances on the surfaces, air pollution, sunlight, temperature, water content of the surface, etc. (4). Hence, preventive conservation requires knowledge of a set of parameters connected to a specific $\mathrm{CH}$ site, including microclimatic conditions (5), mineralogical, textural, petrophysical, and durability characterization studies of mortars. In our case, as documented in the literature on outdoor stone because it is difficult to find frescoes in these conditions (6), other biological factors such as cyanobacteria, lichen, etc., are negligible in front of the above mentioned factors.

The study of the techniques originally used is essential for conservation and restoration, is required in order to understand the original and added materials present both on the surface and within the painting's stratigraphy (7-10). In addition, analytical results can improve a conservator's overall awareness of deterioration processes and mechanisms that influence the condition of wall paintings in 
procesos de deterioro y los mecanismos que influyen en el estado de conservación de las pinturas murales $(11,12)$, datos necesarios para una futura restauración $(13,14)$.

Se sabe que las pinturas murales exteriores se ven especialmente afectadas por los cambios de temperatura y humedad, fenómenos asociados con el deterioro causado por las sales solubles, por la actividad microbiológica, o por daños debidos a actos de vandalismo, iconoclasia, así como el turismo (11). En muchos casos, los nuevos morteros, bien debido a su contenido en sales solubles, su mayor resistencia mecánica o sus diferentes propiedades físicas, han tenido un efecto negativo en la conservación del PC (15). Por lo tanto, son necesarios diferentes estudios antes de comenzar una restauración con el fin de conocer qué tipo de fenómenos están afectando a la obra de arte.

El objetivo global de este trabajo es documentar las condiciones de la conservación y las causas de deterioro de las pinturas murales de la casa de Ariadna para ejecutar una futura restauración intentando prolongar su conservación lo máximo posible. Para ello, se desarrollan estudios multidisciplinares previos a la intervención, incluyendo estudios ambientales, mediciones de radiación electromagnética, estudio de materiales empleados en la ejecución de las pinturas y en restauraciones recientes que podrían generar la aparición de sales, así como un estudio fotográfico.

Específicamente, el objetivo de las técnicas de análisis de materiales será doble, por un lado la caracterización de las pinturas murales para poder proceder a la comparación con la extensa bibliografía ya existente sobre el tema (7, 16-23) y por otro la diferenciación entre los materiales originales de la obra y los añadidos en sucesivas intervenciones de conservación, pudiendo estudiar los fenómenos de degradación de los materiales originales de las pinturas murales, y las interacciones con los modernos, como en el caso de las problemáticas causadas por las cristalizaciones de sales $(24,25)$.

\section{MATERIALES Y MÉTODOS}

\subsection{Estudio microclimático}

La instalación de sensores de temperatura y humedad relativa permite un seguimiento completo, preciso y fiable de las condiciones ambientales, así como la predicción de los mecanismos físico-químicos de degradación, y el estudio de los procedimientos más adecuados para el control de estos (26). general $(11,12)$, providing necessary data for a future restoration $(13,14)$.

It is known that external wall paintings are especially affected by changes in temperature and humidity, deteriorating phenomena associated with soluble salts, microbiological activity, or damage due to vandalism, iconoclasm and tourism (11). In many cases new mortars, whether due to their soluble salt content, their greater mechanical resistance or their different physical properties, had a negative effect on the conservation of $\mathrm{CH}$ (15). Therefore, different studies are needed before a restoration begins in order to know which kinds of phenomena are affecting the artwork.

The objective of this paper is to document the conservation conditions and the causes of deterioration of the wall paintings of Ariadne's house to develop a future restoration trying to prolong its conservation as much as possible. Multidisciplinary studies were developed prior to intervention, including environmental studies, measurements of electromagnetic radiation, study of materials used in the execution of the paintings and in recent restorations that could generate the appearance of salts, as well as a photographic study.

Specifically, the goal of materials analysis techniques will be twofold, on one hand the characterization of the wall paintings in order to proceed to the comparison with the extensive existing literature on the subject (7, 16-23), on the other hand the differentiation between the original materials of the work and added ones in successive conservation interventions, studying the phenomena of degradation of the original materials of the wall paintings, and interactions with the new ones, as in the case of the problems caused by the crystallization of salts $(24,25)$.

\section{MATERIALS AND METHODS}

\subsection{Environmental study}

The application of temperature and $\mathrm{RH}$ sensors permits for a full, accurate and secure monitoring of the environmental conditions and allows for the prediction of physicalchemical mechanisms of degradation, as well as of the most suitable procedures for controlling them (26). 
Con el fin de realizar un estudio ambiental, fueron colocadas 26 sondas, conteniendo, cada una de ellas, un sensor de temperatura y uno de humedad relativa (HR). Una de estas sondas fue colocada en una de las paredes exteriores de la casa para servir como parámetro de control.

Los sensores fueron desarrollados por Maxim Integrated Products, Inc. (Sunnyvale, CA, EE.UU.). Los datos de HR fueron registrados por un DS1923 con una exactitud de $\pm 5 \%$ de humedad relativa y los de temperatura por un DS1922L con una precisión de $\pm 0,5^{\circ} \mathrm{C}$. Los sensores de HR fueron calibrados antes de su instalación como se describe en (27).

Se llevaron a cabo dos estudios ambientales. El primero se elaboró entre 2008 y 2009 (de 23/07/2008 a 30/07/2009) $\mathrm{y}$, dado que el periodo más conflictivo resultó ser el verano, el segundo estudio se realizó únicamente para el verano de 2010 (de 15/7/2010 al 16/10/2010), permitiendo evaluar las consecuencias del cambio realizado en las cubiertas. Los datos fueron tomados cada media hora.

Por otro lado, los estudios microclimáticos fueron combinados con la termografía infrarroja con el fin de completar los resultados obtenidos. La termografía infrarroja es una técnica que nos permite, a cierta distancia y sin contacto directo, medir y mostrar con un sensor infrarrojo la radiación infrarroja emitida por un objeto (28). La cámara utilizada fue una NEC Corporation (Tokio, Japón) TH9260 con una matriz de $640 \times 480$ pixels infrarrojos, una resolución de $0,06{ }^{\circ} \mathrm{C}$ y una gama espectral de 8 a $14 \mu \mathrm{m}$.

\subsection{Mediciones de radiación electromagnética}

Las mediciones de radiación electromagnética son particularmente útiles para el control de monumentos arqueológicos (29). Los espectrómetros CCD permiten la investigación in situ sobre las obras y la medición de los agentes nocivos relacionados con longitudes de onda de radiación electromagnética $(29,30)$.

En este trabajo, las mediciones se llevaron a cabo por un espectrofotómetro portátil. La reflectividad relativa fue calibrada para Blanco Munsell 9. Una fuente de luz de xenón computerizado que emite en el rango de 200 a 1.100 nm (atribuible al Instituto Nacional de EE.UU. de Estándares y Tecnología, NIST) fue utilizada para iluminar los puntos objetivo. Se empleó un espectrómetro avanzado con CCD de rejilla que consiste en un detector SONY ILX511 con 2048 píxeles, empleado para medir reflectividad normal $\left(90^{\circ}\right)$ en el intervalo desde 220 hasta $850 \mathrm{~nm}$. Las señales fueron recogidas por 1.860 píxeles de los 2.040 puntos de la matriz lineal, con 0,37 nm de resolución media y corrección de la luz difusa. Todos los componentes del equipo de trabajo se encontraban de acuerdo a las especificaciones cuando fueron analizados en el Laboratorio de Ciencia
In order to perform an environmental study, 26 probes were placed, each one containing a temperature and a relative humidity $(\mathrm{RH})$ sensor. One of these probes was placed outside of the house serving as a control.

Each sensor was developed by Maxim Integrated Products, Inc. (Sunnyvale, CA, USA). RH were recorded by a $D S 1923$ with an accuracy of $\pm 5 \% R H$, and temperature by a DS1922L with an accuracy of $\pm 0.5^{\circ} \mathrm{C}$. $\mathrm{RH}$ sensors were calibrated prior to their installation as described in (27).

Two environmental studies were performed. The first one was performed between 2008 and 2009 (from 7/23/2008 to $7 / 30 / 2009$ ) and since the most conflicting data appeared in summer, the second study was conducted within the summer of 2010 (from 7/15/2010 to 10/16/2010), to evaluate the consequences of the rooftop change performed. The data are taken every half an hour.

On the other hand, microclimatic studies have been combined with infrared thermography in order to complete the results obtained. Infrared thermography is a technique that allows us, at certain distance and without direct contact, to measure and display with an infrared sensor the infrared radiation emitted by an object (28). The camera used is a NEC Corporation (Tokyo, Japan) TH9260 with an infrared matrix of $640 \times 480$ pixels, a resolution of $0.06{ }^{\circ} \mathrm{C}$ and a spectral range from 8 to $14 \mu \mathrm{m}$.

\subsection{Electromagnetic radiation measurements}

Electromagnetic radiation measurements are particularly useful for the control of archeological monuments (29). CCD spectrometers allow in situ investigation on artworks and the measurement of harmful agents related to electromagnetic radiation wavelengths $(29,30)$.

In this work, the measurements were carried out by a portable spectrophotometer. Relative reflectivity calibrated to Munsell's White 9. A computerized xenon light source that emits in the 200 to $1100 \mathrm{~nm}$ range (traceable to the U.S. National Institute of Standards and Technology, NIST) was used to illuminate the target points. An advanced CCD grating spectrometer consisting of a SONY ILX511 detector with 2048 pixels was used to measure normal $\left(90^{\circ}\right)$ reflectivity in the 220 to $850 \mathrm{~nm}$ range. The signals were collected by 1860 pixels of the 2040 linear array, with $0.37 \mathrm{~nm}$ mean resolution and stray light correction. All the components of the equipment worked according to specifications when tested in the Plant Science Laboratory of NASA Ames Research Center in California, using a calibrating light source "seasoned" at the NIST. Throughout 
de Plantas del Centro de Investigación Ames de la NASA en California, utilizando una fuente de luz calibrada en el NIST. Durante toda la investigación se utilizó un dispositivo portátil de calibración para verificar la calibración de longitud de onda. No fueron necesarios nuevos ajustes.

\subsection{Estudio de materiales}

Las observaciones y el análisis estratigráfico de muestras de pinturas murales de Pompeya se realizaron mediante microscopía óptica y microscopía electrónica de barrido. El microscopio óptico utilizado es el modelo ECLIPSE 80i de Nikon Corporation que lleva acoplada una cámara DSFi1. Las muestras se observaron en modo de luz reflejada con aumentos desde 5x a 50x. La microscopía electrónica de barrido con microanálisis (SEM-EDX) se realizó con un microscopio electrónico de barrido de presión variable modelo S-3400N de Hitachi Ltd. (VP-SEM), equipado con un espectrómetro de rayos $X$ de energía dispersiva (EDX) de Bruker Corporation XFlash $®$ con detector de Silicon drift droplet (SD3), con una ventana de Dura-Berilio ultrafina $(8 \mu \mathrm{m})$ para elementos ligeros, y una resolución energética de $125 \mathrm{eV}$. Las condiciones de trabajo han sido: tensión de aceleración $20 \mathrm{kV}$, tiempo de medición comprendido entre 30 y $100 \mathrm{~s}$, distancia de trabajo de $10 \mathrm{~mm}$. Se tomaron 50 pequeñas muestras de diferentes materiales de los morteros y de las capas pictóricas de las pinturas, que fueron incluidos en resina de poliéster de dos componentes (Presi, MECAPREX SS) y preparadas en sección transversal. Esta preparación permite la observación y el análisis químico elemental de la secuencia estratigráfica de cada muestra y la observación de la apariencia, textura, tamaño de grano, grosor y color de cada capa $(31,32)$.

La identificación de diferentes fases cristalinas se realizó mediante difracción de rayos- $X$ utilizando el método de polvo. Los datos XRD se obtuvieron con un difractómetro de Bruker Corporación D4 Endeavor AXS, con radiación $\mathrm{Cu} \mathrm{Ka} 1$. Las medidas se tomaron con $40 \mathrm{kV}$ y $20 \mathrm{~mA}$, en un rango de $15-70$ a $(2 \theta)$, un paso de $0,05^{\circ}$ y un tiempo de $1,5 \mathrm{~s}$.

Para la analítica de morteros se empleó un espectrómetro de infrarrojos con transformada de Fourier (FTIR) de Bruker Corporación Vertex 70, con un intervalo $4.000-400 \mathrm{~cm}^{-1}$ y una resolución de $4 \mathrm{~cm}^{-1}$. Las muestras se prepararon en pastillas (diámetro $13 \mathrm{~mm}$ ), por presión al vacío con bromuro de potasio seco $(1 \mathrm{mg} / 100 \mathrm{mg}$ de $\mathrm{KBr}$ ) a una presión de 10 toneladas durante 4 minutos.

\subsection{Fotografía}

El tratamiento digital de imágenes ha sido ampliamente utilizado en muchos campos diferentes, como por ejemplo, astrofísica, investigación médica, geográfica y militar. En los últimos años, el tratamiento digital de imágenes se the investigation a portable calibrating device was used to verify the wavelength calibration. No new adjustments were needed.

\subsection{Study of materials}

The observations and stratigraphic analysis of samples of wall paintings from Pompeii have been performed with optical microscopy and scanning electron microscopy. The optical microscope is from NIKON Corporation (Tokyo, Japan) ECLIPSE 80i with a DS-Fi1 camera. Samples have been observed in reflected light at magnifications ranging from $5 x$ to 50x. The scanning electron microscopy with microanalysis (SEM-EDX) was performed with a scanning electron microscope of variable pressure from Hitachi LTD (VP-SEM) S-3400N, equipped with energy dispersive X-ray

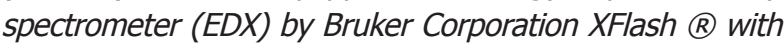
Silicon Drift Droplet detector (SD3), supra light element window/8 $\mu \mathrm{m}$ Dura-Beryllium window, and an energetic resolution of $125 \mathrm{eV}$. With working conditions: accelerating voltage $20 \mathrm{kV}$, measuring time between 30 and $100 \mathrm{~s}$, working distance $10 \mathrm{~mm}$. This research has been performed taking small samples of different materials from the mortars and pictorial layers of frescoes, which have been included in a bi-component polyester resin of self-curing (Presi, MECAPREX SS) and prepared in cross section. This preparation allows for observations and elemental chemi$\mathrm{cal}$ analysis of the stratigraphic sequence of each sample and the observations of appearance, texture, grain size, thickness and color observations of each layer $(31,32)$.

The identification of different crystalline phases has been performed by $X$-ray diffraction by the method of crystalline powder method. XRD data were obtained with a Bruker Corporation (MA, USA) D4 Endeavor AXS diffractometer, with $\mathrm{Cu}$ Ka1 radiation. The measures were taken with 40 $\mathrm{kV}$ and $20 \mathrm{~mA}$, in a range of 15-70th (20), a step of $0.05^{\circ}$ and a collection time of $1.5 \mathrm{~s}$.

For the analytical of mortars a Fourier transform infrared spectrometer (FTIR) from Bruker Corporation Vertex 70, in the range 4000-400 cm-1 with a resolution of $4 \mathrm{~cm}-1$ was used. Sample tablets were prepared (diameter $13 \mathrm{~mm}$ ), pressed by dry potassium bromide $(1 \mathrm{mg} / 100 \mathrm{mg} \mathrm{KBr}$ ) at a pressure of 10 tons for 4 minutes in vacuum.

\subsection{Photography}

The digital treatment of images has been widely used in many different fields, as for instance, astrophysical, medical, geographical and military research. In the last years, digital elaboration of the images has also been used in the 
ha utilizado también en el campo de la conservación del PC (33). De hecho, la fotografía profesional, especializada en arte y restauración, ofrece una nueva visión para la documentación fotográfica científica (34).

Se utilizó una cámara digital Hasselblad EE.UU. Inc. con un CCD de 55 × $41 \mathrm{~cm}$ y 6.496 × 4.872 píxeles. Las fotos fueron tomadas con una velocidad de obturación de 1/125 y diafragmas f16 o f11. El número de imágenes tomadas fue superior a 700 .

Como la luz solar que ilumina las pinturas es insuficiente y ofrece resultados de muy baja calidad, en este estudio se utilizó un flash Bron Elektronik AG Verso Broncolor de tamaño A4 con una pantalla difusora y totalmente protegidos de la radiación UV.

El flash se colocó aproximadamente a dos metros de distancia del objeto y a un ángulo de incidencia de 45 grados.

Se tomaron fotografías de falso color IR con una cámara de Sony Corporation, modelo DSC-F828 que cuenta con un CCD Super HAD. Esta cámara es capaz de eliminar el filtro visible (filtro de corte IR).

Para obtener una fotografía infrarroja de falso color se empleó la técnica descrita por Moon et al (35) con una modificación. El canal azul fue sustituido por el nuevo canal de la fotografía de infrarrojos. Esta técnica es ampliamente utilizada (36).

\section{RESULTADOS Y DISCUSIÓN}

Mediante la combinación de diferentes enfoques metodológicos (estudios de las condiciones ambientales, estudio de los materiales, fotografía, etc.), fue posible determinar los principales problemas de conservación que afectan a la casa de Ariadna para una futura decisión de las técnicas más convenientes a emplear en su restauración (37).

\subsection{Estudio ambiental}

La ciudad romana de Pompeya presenta un clima extremo (Figura 2), con grandes fluctuaciones entre la noche y el día, estas fueron, en verano de 2008 en promedio de un $15 \%$ para $\mathrm{HR}$ y de $6,5^{\circ} \mathrm{C}$ para la temperatura.

Las fluctuaciones bruscas resultan perjudiciales para la conservación de los frescos, ya que estos cambios producen su deterioro (38). Al tratarse de un lugar arqueológico al aire libre, el clima exterior condiciona el clima de las salas, por ello las actuaciones técnicas deben tratar de amortiguar estas variaciones, suavizar los máximos y los mínimos, creando un ambiente lo más uniforme posible. field of $\mathrm{CH}$ conservation (33). In fact, professional photography, specialized in art and restoration, gives a new vision for scientific photographical documentation (34).

A digital camera Hasselblad USA Inc. (WA, USA) whith a $55 \times 41 \mathrm{~cm} C C D$ of $6496 \times 4872$ pixels was used. The shots were taken with a shutter speed of $1 / 125$ and f16 or f11 aperture. The number of taken images taken exceeds 700.

As the solar light falling on the paintings is inadequate and provides very low quality results, in this study we used a Bron Elektronik AG (Allschwil, Switzerland) Broncolor Verso $A 4$ with a diffusing screen and fully protected from UV radiation.

The flashes were placed approximately two meters away from the object at an incident angle of 45 degrees.

False-color IR photographs were taken by a SONY Corporation (Tokyo, Japan) camera, model DSC-F828 equipped with a Super HAD CCD. This camera is capable of removing the visible filter (IR-cut filter).

To obtain a false-color infrared photography a modified (35) technique has been used. The blue channel was substituted by a new channel from IR photography. This technique is widely used (36).

\section{RESULTS AND DISCUSSION}

By combining different methodological approaches (studies of environmental conditions, study of materials, photography, etc.) it was possible to determine the main problems affecting Ariadne's house for preventive conservation and for a future decision of the most convenient techniques of restoration to be used (37).

\subsection{Environmental study}

The roman city of Pompeii presents an extreme weather (Figure 2), with big fluctuations between night and day, in summer 2008 an average of for $\mathrm{RH}$ and $6.5^{\circ} \mathrm{C}$ for temperature.

Abrupt weather fluctuations are detrimental to conservation since extreme changes produce deterioration (38). As an open-air archaeological site, the outdoor climate determines the climate of the rooms, thus, the technical actions should aim to cushion these jumps, smoothing the maximums and minimums for a uniform environment whenever possible. 




Figura 2. Valores medios diarios de temperatura y humedad relativa exterior de la casa de Ariadna del 23/07/2008 al 30/07/2009. Figure 2. Ariadne's house daily values of outdoor temperature and RH from 07/23/2008 to 07/30/2009.

El análisis exploratorio realizado en el período 2008-2009 detectó diferentes microclimas en las salas, en función de las cubiertas y techos utilizados. A saber (Figura 3-a) un microclima para el techo de teja (sala 4, Figura 1), otro para las cubiertas de policarbonato (salas 1, 2 y 3, Figura 1) y otro para la cubierta de cristal (mosaico). La cubierta opaca (teja, sala 4) configuraba un microclima más adecuado en verano, con mayor atenuación de los cambios climáticos exteriores, tanto en temperatura como en HR. Efecto similar durante el invierno pero de menor intensidad.
Exploratory analysis performed in 2008-2009 showed that different microclimates occurred in the rooms depending on the covers and roofs used. A microclimate for the tile roof (room 4, Figure 1), another for the polycarbonate covers (rooms 1, 2 and 3, Figure 1) and yet another for the glass cover (mosaic) were detected (Figure 3-a). The opaque cover (room 4) configured a suitable microclimate in summer, dimming the exterior climate changes, both in temperature as in $\mathrm{RH}$. During winter it had a similar effect, but of less intensity.

A)

- - Exterior / Outdoor — Habitación / Room 4 …... Mosaico / Mosaic — Habitación / Room 1, 2, 3
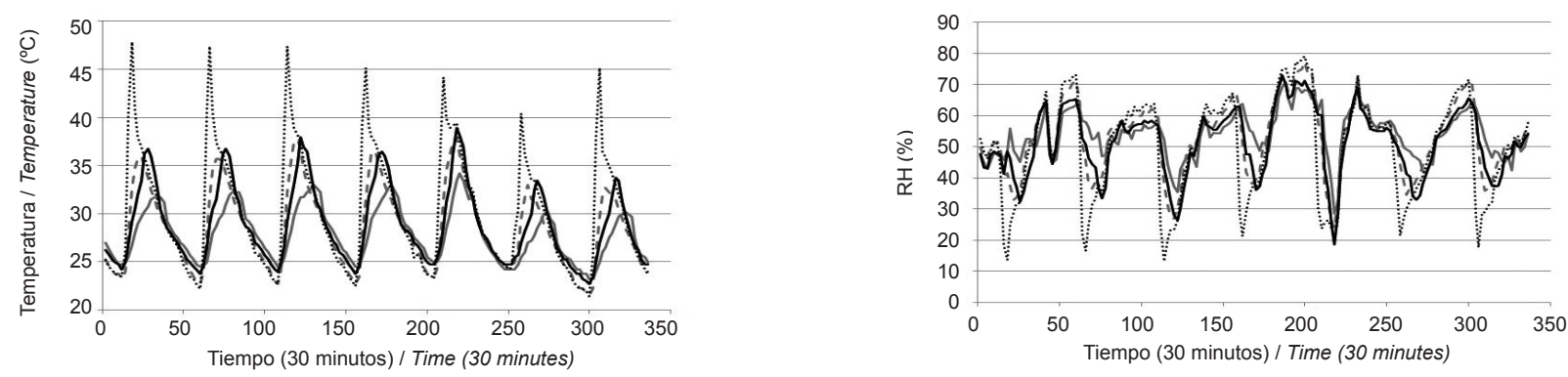

B)
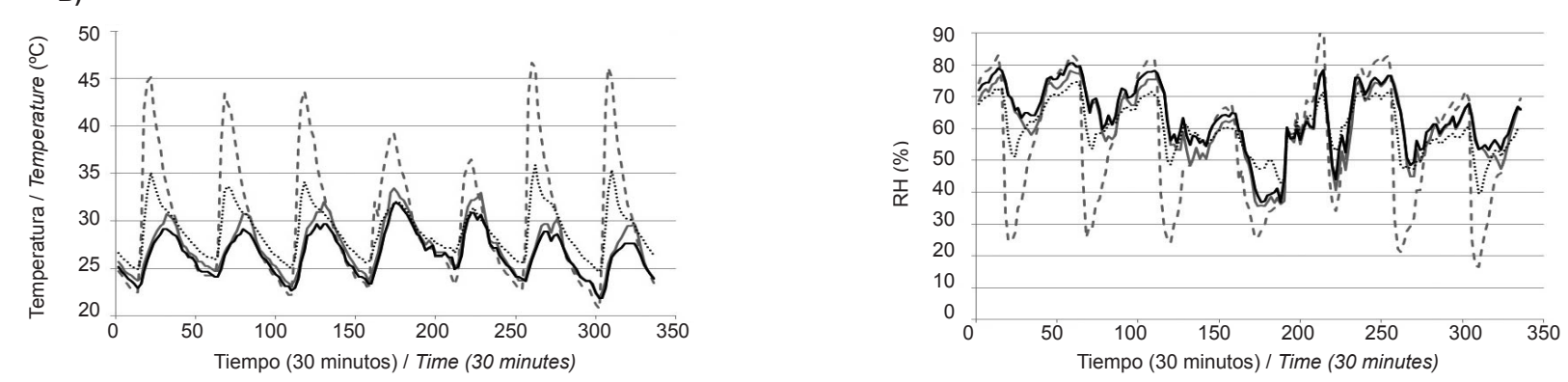

Figura 3. Comparación de los valores de temperatura $\left({ }^{\circ} \mathrm{C}\right)$ y humedad relativa $(\%)$ de una semana de verano en a) 2008 y b) 2010 para los distintos microclimas de la casa de Ariadna. El tiempo 0 corresponde al 11 de agosto de 2008, 00:00 horas. Datos cada media hora.

Figure 3. Comparison of values of temperature $\left({ }^{\circ} \mathrm{C}\right)$ and $\mathrm{RH}(\%)$ of a summer week in a) 2008 and b) 2010, for the different microclimates of Ariadne's house. Time 0 corresponds to August 11th 2008, 00:00 hours. Data every half hour. 
Sin embargo, las cubiertas transparentes de policarbonato (salas 1, 2 y 3, Figura 1) ocasionaban un efecto invernadero en verano, con valores similares para los parámetros meteorológicos a los del microclima exterior (Figura 3-a).

Finalmente, la cubierta de cristal del mosaico de los peces proporcionaba el microclima más perjudicial de todos debido a las grandes variaciones de temperatura y HR (Figura 3). Se aconseja no poner esta cubierta al mosaico, puesto que ya está protegido de la lluvia por el techo de la habitación.

A partir de los resultados anteriormente descritos, se tomaron decisiones con el fin de paliar los efectos de este tipo de cubiertas. Así, se cambiaron los tejados en las salas 1,2 y 3 donde existían cubiertas transparentes.

Las condiciones ambientales que más se alejan de las recomendadas en la norma UNI 10829 (39) para la conservación de los frescos tienen lugar durante el verano, con cambios más bruscos día/noche tanto en temperatura como en HR. Con el fin de evaluar los efectos del cambio de cubierta, se realizó un segundo estudio microclimático únicamente para los meses de verano del 2010. Los resultados obtenidos en el análisis exploratorio muestran cómo la temperatura y HR han sufrido una variación positiva del verano de 2008 al verano de 2010 como consecuencia del cambio de tejados. En 2010 el promedio de la temperatura en las salas disminuyó con respecto a la exterior, debido a la disminución de los máximos (Figura 3-a). Además en 2010, la HR aumentó en promedio con respecto a la exterior, debido al aumento de los mínimos. La temperatura y la HR redujeron su variabilidad y se suavizaron los cambios diarios extremos. Asimismo, en 2010 las principales diferencias entre los microclimas obtenidos en 2008 para HR y temperatura desaparecieron (Figura 3).

De otro lado, el uso de una técnica complementaria, la termografía, permitió evaluar el cambio de microclima producido por los nuevos tejados. Los resultados han demostrado que el cambio de los tejados ha generado una modificación sustancial en el gradiente y los valores de temperatura en las habitaciones (Figura 4), al igual que se ha mostrado en el estudio microclimático. La termografía posee una ventaja sobre los data-loggers ya que permite evaluar zonas de menor temperatura debido a que se produce evaporación de agua o la existencia de cavidades o levantamientos.

Resumiendo, el estudio ambiental ha permitido reconocer las perjudiciales condiciones climáticas en las salas de la casa de Ariadna y proporcionar la solución más adecuada (cambio de tejados). Asimismo, la termografía (Figura 4), ha cuantificado la diferencia en el gradiente de temperatura en el verano de 2008 es de 22 grados centígrados, mientras que en 2010 este se reduce hasta aproximadamente solo
However, the transparent polycarbonate cover (rooms 1, 2 and 3, Figure 1) produced a greenhouse effect, with similar weather parameter values to the outdoor microclimate (Figure 3-a).

Finally, the glass coverage of the fish mosaic provides the most damaging conditions of all micro-climates due to large variations in temperature and $\mathrm{RH}$ (Figure 3). It is advised not to put this covering on the mosaic since it is protected from rain by the roof of the room.

After having these results, decisions for solutions were taken in order to palliate the effects of this kind of covers. Thus, a rooftop change was performed in rooms 1, 2 and 3 where transparent covers were installed.

Environmental conditions further away from those recommended in the standard UNI 10829 (39) for the conservation of frescoes appeared in summer, when abrupt day/night temperature shifts as well as in $\mathrm{RH}$ appeared. Thus, in order to evaluate the effects of the roof change, a second microclimate study was performed only for the summer months in 2010. The obtained results from exploratory analysis show how temperatures and $\mathrm{RH}$ have suffered a positive variation from summer 2008 to summer 2010 as a consequence of the rooftop change performed. In 2010 the average temperature in the room decreased with respect to the outside, due to the decrease of the maximum temperature (Figure 3-a). Also in 2010, the RH increased on average with respect to the exterior, due to the increase of the minimum. Temperature and $\mathrm{RH}$ have stabilized, reducing its variability and smoothing those extreme daily changes. On the other hand, in 2010 the main differences between microclimates obtained in 2008 for RH and temperature have disappeared (Figure 3).

On the other hand, the use of a complementary technique, thermography, allowed us to assess the changes obtained with the new roofs. The results have shown that changing the rooftops has generated a substantial modification in the temperature gradient and values of the rooms (Figure 4), as well as the microclimatic study showed. Thermography has an advantage over the data-loggers since it allowed evaluating areas with lower temperature due to evaporation of water or problems such as cavities or uprisings.

Summarizing, the environmental study has allowed us to acknowledge the detrimental microclimatic conditions in Ariadne's house rooms, providing an adequate solution (change of roofs). Also it has been possible to evaluate the positive consequences of changing the rooftops (Figure 4). We can see that the difference in temperature gradient in summer 2008 is 22 degrees Celsius, while 


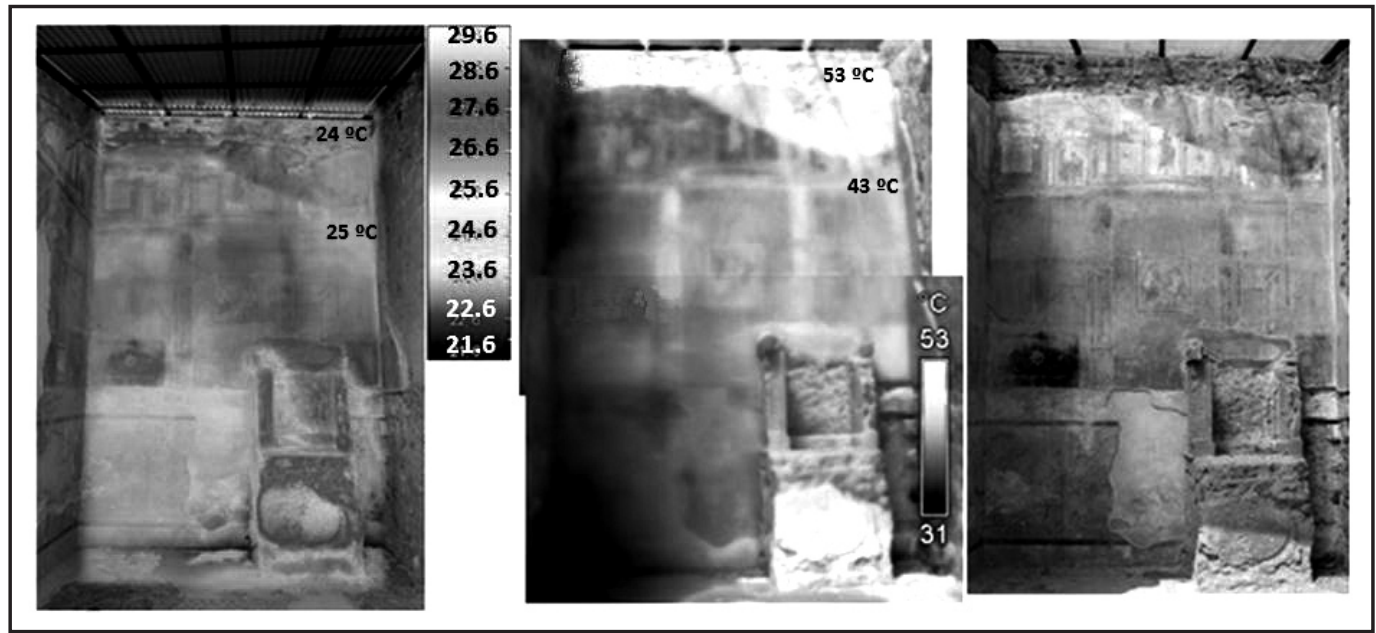

Figura 4. Sala 1, de izquierda a derecha: en 2010 termografía, en 2008 termografía, imagen real de 2008. Estas figuras muestran el cambio de tejado realizado y el consecuente beneficio.

Figure 4. Room 1, from left to right: 2010 thermography, 2008 thermography, 2008 real image (room 1). These Figs. show the roof change performed and its subsequent benefits on temperature.

7 grados centígrados en un día a la misma hora con temperaturas e insolación similares.

Téngase en cuenta, que si no se hubiese realizado este cambio de cubierta, una futura restauración habría sido inútil y fugaz.

\subsection{Mediciones de radiación electromagnética}

Los murales en la casa de Ariadna en Pompeya están expuestos diariamente a la luz del sol. Teniendo en cuenta los posibles daños de esta radiación electromagnética sobre las pinturas, sobre todo ultravioletas, se han realizado mediciones de la radiación solar y de los filtros en las diferentes habitaciones de la casa.

Como se ha mencionado, los techos de policarbonato fueron instalados en las habitaciones 1-3 (Figura 1) de la casa donde los frescos cubren las paredes de arriba a abajo. Las propiedades de filtrado del policarbonato cambian con los años, perdiendo la capacidad de absorber parte de la radiación dañina y la transparencia a la luz visible (40).

Así pues se midió la eficacia de los filtros instalados y se comparó con otros que fueron considerados como posibles opciones para proteger las pinturas, como diferentes tipos de filtros de acrílico.

Se consideraron los filtros como Reflectiv (Bonneuil-surMarne, Francia) SOL 259 interior, que es una película de poliéster de 36 micras que tiene color humo, que bloquea el $95 \%$ de la radiación ultravioleta sin cancelar la luz visible con una transmisión del $11 \%$, lo que permite la in 2010 this gradient is reduced to about only 7 degrees Celsius.

Note that if a roof change had not been performed a future restoration would have been useless.

\subsection{Electromagnetic radiation measurements}

The murals in Ariadne's house in Pompeii are exposed daily to the sunlight. Considering the possible damages of this electromagnetic radiation to the paintings, particularly ultraviolet, measurements of solar radiation and of filters have been taken in the different rooms of the house.

As mentioned, polycarbonate rooftops were installed on rooms 1-3 (Figure 1) of the house where frescoes cover the walls from top to bottom. Some areas of the frescoes are exposed to direct sunlight, because the rooftops not cover completely the artworks. Furthermore, the filtering properties of the polycarbonate change over the years loosing the capacity to absorb some of the harmful radiation and transparency to the visible light (40).

The effectiveness of the installed filters was measured and they were compared with others that were considered as possible options to protect the paintings, such as different types of acrylic filters.

We considered filters such as Reflectiv (Bonneuil sur Marne, France) SOL 259 interior, which is a 36 microns polyester film that has smoke color. It blocks $95 \%$ of the Ultraviolet radiation without canceling the visible light with an $11 \%$ transmission, which allows for daylight viewing 
visualización de la luz del día con una reducción del efecto invernadero y un bloqueo de la radiación UV. Otro filtro considerado fue el UVA 109, filtro que tiene características similares y es también una película de poliéster de 36 micras, pero tiene la ventaja de que bloquea la radiación UV hasta el $99 \%$ y también es más transparente a la luz visible, permitiendo un $73 \%$ de transmisión. with a reduction of the greenhouse effect and a blockage of the UV radiation. Another filter considered was the UVA 109 filter that has similar characteristics and is also a 36 micron polyester film, but it has the advantage that it blocks UV radiation up to $99 \%$ and is also more transparent to visible light, allowing $73 \%$ transmission.



Figura 5. Comparación de la eficacia de filtros de policarbonato y poliéster (Sol 259, UVA 109) bajo la influencia de la radiación solar. Todos estos filtros son eficientes, pero Sol 259 tiene las mejores propiedades de filtrado en la banda ultravioleta $(280-400 \mathrm{~nm})$, además es el más transparente a la luz visible.

Figure 5. Comparison of the effectiveness of polycarbonate and polyester filters (Sol 259, UVA 109) under the influence of solar radiation. All these filters are efficient, but Sol 259 has the best filtering properties in the Ultraviolet band $(280-400 \mathrm{~nm})$ while it is the most transparent to the visible light.

El análisis (Figura 5) muestra que el policarbonato absorbe/refleja una gran proporción de los rayos ultravioleta, pero esto se mejora cuando se añade otro filtro. Los filtros de poliéster no bloquean suficientemente la radiación ultravioleta dañina. Si estos filtros fuesen reemplazados por un techo no transparente, como la madera o tejas, la radiación dañina que llega a las pinturas desde el techo sería cercana a cero.

A su vez, algunas áreas de los frescos están expuestas a la luz solar directa, porque las salas tienen amplias aberturas verticales al exterior. Los resultados sin filtros a las 12:30 PM en verano fueron los siguientes: $6 \mu \mathrm{W} / \mathrm{cm}^{2} / \mathrm{nm}$ de B ultravioleta a $280 \mathrm{~nm}$ y $9 \mu \mathrm{W} / \mathrm{cm}^{2} / \mathrm{nm}$ de $319 \mathrm{~nm}$. En la banda UV-A $10 \mu \mathrm{W} / \mathrm{cm}^{2} / \mathrm{nm}$ a $322 \mathrm{~nm}$ y $48 \mu \mathrm{W} / \mathrm{cm}^{2} / \mathrm{nm}$ a $390 \mathrm{~nm}$. Teniendo en cuenta que la UV debe estar lo más cercana a cero posible, estos datos muestran la necesidad de utilizar un filtro solar para preservar las pinturas.

Los datos obtenidos en este trabajo muestran una gran cantidad de radiación solar que baña los frescos de la casa de Ariadna. Por lo tanto, como conclusión de este
The analysis (Figure 5) shows that the polycarbonate absorbs/reflects a great portion of Ultraviolet, but this is further enhanced when another filter is added. Polyester filters do not block enough the harmful solar ultraviolet radiation. If these filters were replaced by a non-transparent roof, such as wood or tiles, the harmful radiation reaching the paintings from the roof would be close to zero.

In turn, some areas of the frescoes are exposed to direct sunlight, because the rooms have large outdoor vertical openings. Results without filters at 12:30 PM in summer were: $6 \mu W / \mathrm{cm}^{2} / \mathrm{nm}$ of Ultraviolet $B$ at $280 \mathrm{~nm}$ and $9 \mu \mathrm{W} / \mathrm{cm}^{2} / \mathrm{nm}$ at $319 \mathrm{~nm}$. In the $U V-A$ band $10 \mu W / \mathrm{cm}^{2} / \mathrm{nm}$ at $322 \mathrm{~nm}$ and $48 \mu W / \mathrm{cm}^{2} / \mathrm{nm}$ at $390 \mathrm{~nm}$. Considering that the UV must be as close to cero as possible, these data showed the necessity of using a solar filter to preserve the paintings.

The data obtained in this work shows a considerable amount of solar radiation that bathes the frescoes in Ariadne's house. Therefore, as a conclusion of this 
estudio de radiación electromagnética, coincidiendo con otras técnicas aplicadas en el presente trabajo, los techos de policarbonato están afectando a la preservación de las pinturas murales.

\subsection{Estudio de materiales}

A continuación se presentan los resultados desde la capa estratigráfica más externa a la más interna.

En primer lugar, se ha encontrado una fina capa de tonalidad grisácea que recubre uniformemente casi todas las superficies policromadas. El análisis por SEM-EDX ha identificado la presencia de compuestos a base de sulfato de calcio y compuestos de silicio, aluminio y potasio, elementos generalmente presentes en el suelo de la sedimentación volcánica y en los contaminantes del medio ambiente que caracterizan la zona arqueológica de Pompeya (41).

En segundo lugar, mediante microscopía óptica, se realizó un estudio de las capas de pintura. Se determinó que el espesor de esta capa no es regular y varía de un mínimo de 10-20 micras a un máximo de 110 micras aproximadamente. En el estudio SEM-EDX de las capas de pintura (Figura 6) se detectó la presencia de calcio. Este elemento, que aparece constantemente en las muestras, está atribuido al uso de cal (carbonatación del mortero fresco o mezcla de cal con pigmentos y agua). electromagnetic radiation study in coincidence with other techniques applied in the present work, the polycarbonate roofs are affecting the wall paintings preservation.

\subsection{Study of materials}

Below the results from the stratigraphic layer outermost to the innermost are showed.

First, note that the polychrome surface is affected by the presence of a thin layer of diffuse grayish hue. The SEMEDX analysis has identified compounds based on calcium sulfate and silicon compounds, aluminum and potassium, elements usually present in the volcanic soil of sedimentation and pollutants from the environment of the archaeological site of Pompeii (41).

Secondly, by optic microscopy, a study of the layers of paint was performed. It was determined that the thickness of the paint layers is not regular, it varies from a minimum of 10-20 microns to a maximum of approximately 110 microns. In the SEM-EDX study of the paint layers (Figure 6) was also detected the presence of calcium. Elements attributed to the use of lime (carbonation of fresh mortar or mixture of water lime with pigments) that appeared constantly in the samples.



Figura 6. SEM-EDX estudio de las capas de pintura: a) Microanálisis donde se detecta la presencia de calcio, cobre y silicio, que sugieren la presencia de silicato de cobre y calcio (cuprorivaíta) (azul Egipcio o Caeruleum). b) Microanálisis donde se detecta la presencia de mercurio y azufre que sugieren la presencia de cinabrio (rojo Pompeyano o Minium).

Figure 6. SEM-EDX study of the paint layers: a) Microanalysis detecting the presence of calcium, copper and silicon, that suggest the presence of copper silicate (Blue Pompeii or Cearuleum). b) Microanalysis detecting the presence of mercury and sulfur that suggest the presence of cinnabar (Red Pompeii or minium).

Los estudios anteriormente descritos han permitido identificar las distintas capas de preparación de las pinturas, permitiendo demostrar que unas pinturas fueron ejecutadas con la técnica pictórica "al fresco" y otras con la técnica "al secco" (42). Los pigmentos identificados se muestran en la Tabla 1.
The studies described above have identified the various layers of preparation, allowing to demonstrate that some paintings were executed with the painting technique "al fresco" and others with the technique "al secco" (42). The identified pigments are shown in Table 1. 
Tabla 1 / Table 1

Pigmentos identificados en las pinturas murales de la Casa de Ariadna en Pompeya.

Pigments identified in the wall paintings of Ariadne's House in Pompeii.

\begin{tabular}{|c|c|c|}
\hline Color / Colors & Nombre antiguo / Old name & Composición / Composition \\
\hline Blanco / White & Creta calcárea / Creta calcarea & Carbonato de calcio / Calcium carbonate \\
\hline Amarillo / Yellow & Ochra & Ocre amarillo a base de hidróxido de hierro / Yellow ochre iron hydroxide base \\
\hline Rojo / Red & Rubricae & $\begin{array}{c}\text { Ocre roja a base de óxidos de hierro con Si, Al, Ca y Mg / } \\
\text { Red Ochre based on iron oxides with Si, Al, Ca and Mg } \\
\text { Cinabrio / Cinnabar }\end{array}$ \\
\hline Verde / Green & Minium & $\begin{array}{c}\text { Tierra verde a base de arcilla coloreada por silicatos de hierro / } \\
\text { Green earth from clay colored by iron silicates }\end{array}$ \\
\hline Azul / Blue & Creta viridis & $\begin{array}{c}\text { Azul Egipcio a base de silicato de cobre y calcio / } \\
\text { Egyptian blue based on copper and calcium silicate }\end{array}$ \\
\hline
\end{tabular}

En tercer lugar, los resultados de los estudios estratigráficos y de los morteros mediante las técnicas instrumentales como la microscopía óptica, la microscopia electrónica de barrido con microanálisis (SEM-EDX) y los análisis de difracción de rayos-X (DRX), muestran que las pinturas murales tienen una estratigrafía compuesta de, al menos, 3 capas de morteros de diferentes espesores (Figura 7), sobre los cuales se encuentran las capas de policromía.

La capa inferior de mortero gris (arriccio) identificado, está elaborado con un aglomerante blanco de carbonato de calcio, y un árido a base de silicatos de aluminio hidratados, sílice, óxidos de hierro, potasio, sodio y magnesio (pozzolana). Las capas sucesivas de mortero presentan color blanco (intonaco e intonachino), y están constituidos por un aglomerante de carbonato de calcio y árido formado por calcita, con cantidades menores de cuarzo, ferrocalcita, dolomita y compuestos de arcilla. El intonachino resulta ser más fino y tiene menos áridos que el intonaco.
Third, the results of stratigraphic and mortars studies using instrumental techniques such as optical microscopy, scanning electron microscopy analysis with microanalysis (SEM-EDX) and X-ray diffraction (XRD) show that the wall paintings have a stratigraphy composed of at least 3 layers of mortars of different thicknesses (Figure 7), on which lie the layers of polychromy.

The lower layer of gray mortar (arriccio) identified, is made with a white binder of calcium carbonate, and silicate-based aggregate of hydrates of aluminum, silica, iron oxide, potassium, sodium and magnesium (pozzolana). Successive layers of mortar are presented in white color (intonaco and intonachino), prepared with a calcium carbonate binder and arid formed by calcite, with minor amounts of quartz, ferrocalcita, dolomite calcite and clay compounds. Intonachino is thinner and has lower arids aggregated than intonaco.

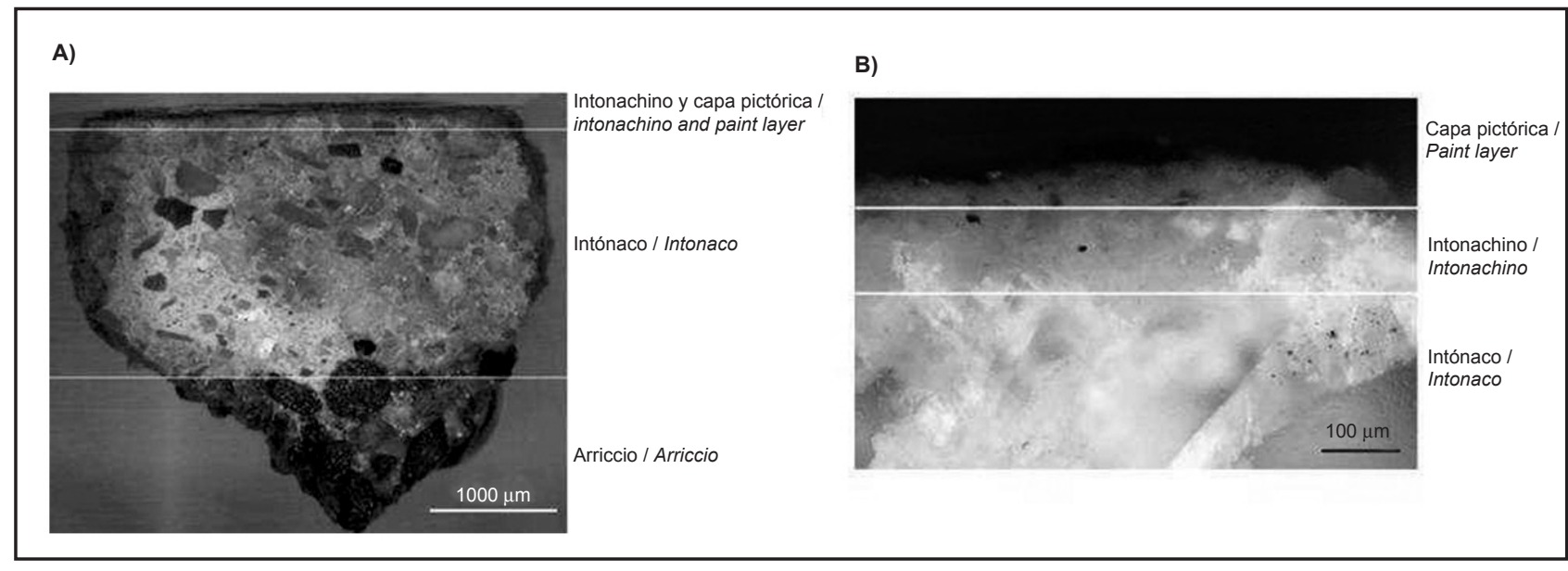

Figura 7. a) Sección transversal obtenida con microscopio estereoscópico (2x). b) Sección transversal obtenida con microscopia óptica (50x). Se observan las diferentes capas de mortero y el estrato pictórico amarillo. De arriba a abajo, capa pictórica, intonachino, intonaco y arriccio.

Figure 7. a) Cross-section obtained with optical microscopy (2x). b) Cross-section obtained with optical microscopy (50x). The different layers of mortar and the yellow paint layers are observed. From top to bottom, paint layer, intonachino, intonaco and arriccio. 
Por otro lado, las técnicas de difracción de rayos- $X$ y de espectroscopia infrarroja por transformada de Fourier (FTIR), se utilizaron para analizar muestras de morteros que se añadieron en anteriores intervenciones de restauración (43). Los resultados de estos estudios, muestran generalmente la presencia de estucados a base de morteros de cal, cal hidráulica o morteros de cementos. También se observa el uso de materiales del lugar de recuperación (material lávico, pómez, material refractario, etc.), creando estucados o materiales de rellenos de naturaleza cementicia con la presencia de áridos y otros componentes de diferente composición.

En último lugar, se detectó el fenómeno más preocupante para la conservación futura de las pinturas murales que es la cristalización de sales solubles por debajo del estrato de policromía. Este fenómeno afecta a todas las capas pictóricas y sus efectos visibles son la aparición de grandes áreas de policromía con un aspecto polvoriento (Figura 8 a) y el desprendimiento de las capas más superficiales de pintura. Mediante microscopía óptica se observó (Figura 8 b), que la cristalización se desarrollaba en el interior de la estructura del soporte, provocando, el desprendimiento de los estratos más superficiales (fenómenos de la sub-eflorescencia). Téngase en cuenta que tras poner de manifiesto la existencia de sales a la hora de una futura restauración será necesario realizar un mapeo muy completo de la zona para determinar las zonas concretas de afectación.
On the other hand, X-ray diffraction (XRD) and Fourier transform infrared spectroscopy (FTIR) was used to analyze samples of original mortars and those of mortars that have been added in previous building interventions (43). The results of these studies generally show the presence of coated based mortar of lime, hydraulic lime or cement mortar. Also show the use of materials of the archeological site (lava material, pumice, refractory material, etc.), creating coated or filled materials of cement nature with the presence of aggregates and other components of different composition.

Finally, the more worrying phenomenon for the future conservation of wall paintings was detected, that is the crystallization of soluble salts below the layer of polychrome. This phenomenon affects all paint layers and their visible effects are the appearance of large areas of polychrome with a dusty appearance (Figure 8 a) and detachment of the outermost layers of paint. By optic microscopy (Figure 8 b), it was observed that the crystallization was developed inside the supporting structure, causing the detachment of the more superficial layers (sub-efflorescence phenomenon). Note that after highlighting the existence of salts at the time of a future restoration will be required a comprehensive mapping of the area to determine specific areas of involvement.

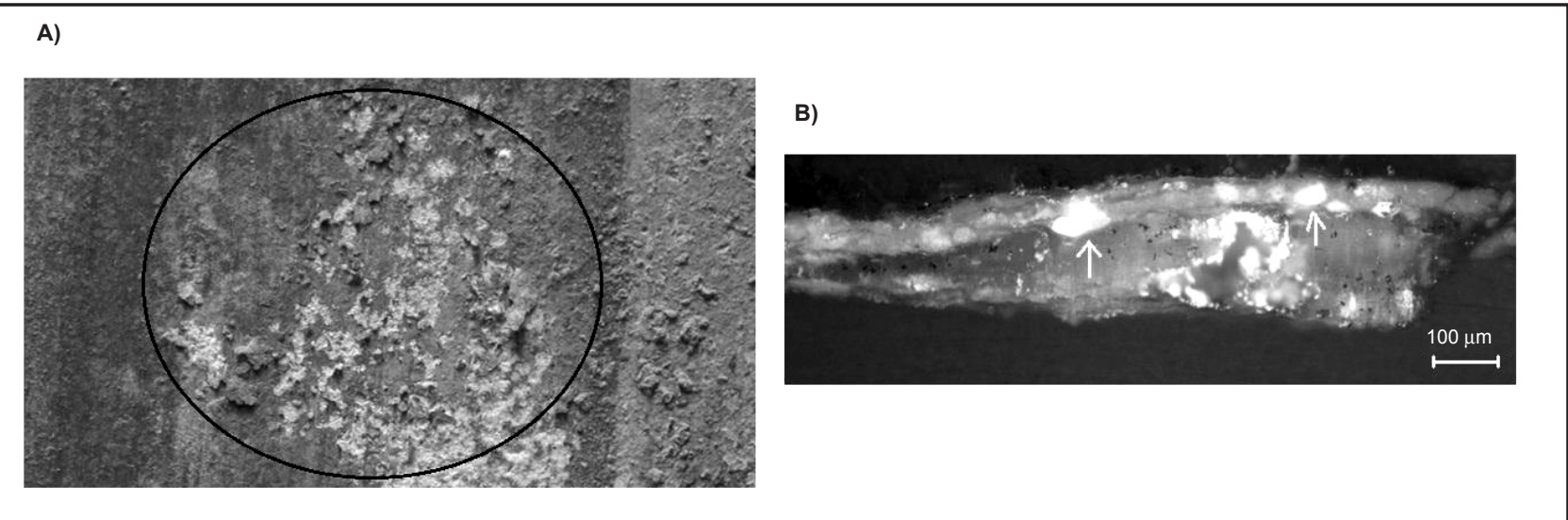

Figura 8. a) Detalle de la pintura mural presente en la casa de Ariadna en Pompeya. Se observa el fenómeno de alteración de la capa de policromía por cristalización de sales (círculo). b) Sección de una muestra de policromía roja por microscopía óptica (10x). Se observa la cristalización de sulfatos por debajo del estrato de policromía (flechas).

Figure 8. a) Detail of Ariadne's house mural painting in Pompeii. The alteration of the polychrome layer by crystallization of salts is observed (circle). b) Section of a sample of red polychromy by light microscope (10x). Crystallization of sulfates is observed below the stratum polychrome (arrows).

Las sales, que han sido caracterizadas mediante análisis XRD, están constituidas principalmente por sulfato de calcio hidratado (yeso), sulfato de sodio y sulfato de potasio, productos que suelen ser generados por la presencia de sulfatos de metales alcalinos $\left(\mathrm{Na}_{2} \mathrm{O}\right.$ y $\left.\mathrm{K}_{2} \mathrm{O}\right)$, presentes en los materiales de construcción y de restauración utilizados
The salts, which have been characterized by XRD analysis are mainly determined by the presence of calcium sulfate (gypsum), sodium sulfate and potassium sulfate, products that can be generated by the presence of alkaline salts $\left(\mathrm{Na}_{2} \mathrm{O}\right.$ and $\left.\mathrm{K}_{2} \mathrm{O}\right)$ in the building materials used in recent times (44) (gypsum, ettringite and thaumasite, which 
en los últimos tiempos (44) (yeso, ettringite y thaumasite, que se originan a través de la reacción del cemento Portland con los compuestos del azufre).

El deterioro que afecta a las pinturas murales de la casa de Ariadna, producido por la cristalización de sales, requiere la eliminación o la reducción de las contribuciones de estas soluciones salinas, es decir, la eliminación mecánica de los morteros utilizados en el pasado siglo para la consolidación estructural de las pinturas. Sin embargo, dado que estas pinturas murales se sitúan en su contexto original, en un sitio arqueológico al aire libre, las medidas para eliminar o reducir la concentración de contaminantes no son fáciles de aplicar ya que estos pueden provenir de las casas adyacentes o del suelo. Entre las soluciones que pueden retardar el proceso de deterioro se puede resaltar un control de los ciclos de cristalización y los mecanismos de evaporación de las soluciones salinas mediante el seguimiento de los parámetros ambientales y creación de barreras de humedad en las paredes de la casa para evitar la humectación por capilaridad.

Además resulta necesaria una intervención conservativa directa sobre las pinturas, para prevenir el desprendimiento de las capas de policromía mediante la aplicación de específicas metodologías de restauración, como pueden ser la pre-consolidación, los tratamientos de eliminación de sales y la consolidación de los estratos de color al soporte y su posterior protección.

En resumen, es importante destacar la necesidad de un seguimiento periódico de las intervenciones, a través de un control del estado de conservación de las pinturas (45, 46), el estudio del soporte (47) y la compatibilidad de los materiales de restauración con la obra y con los contaminantes del medioambiente.

\subsection{Fotografía}

Los resultados obtenidos con la fotografía de alta resolución digital, la fotografía de infrarrojos y la fotografía infrarroja de falso color, pueden ser muy útiles en la restauración. Con ellos se obtiene información que a menudo escapa a nuestra visión, especialmente si se complementa o combina con otras técnicas, como en este trabajo, como la reflectografía infrarroja, multiespectral, termografía, etc.

La fotografía Infrarroja en falso color es una técnica complementaria interesante para el estudio y caracterización de los objetos, en especial la identificación de pigmentos (35). La Figura 9 es útil para una explicación más detallada de esta técnica, donde se pueden ver más detalles y una mayor definición de las líneas y contornos que serían esenciales para una futura restauración. originate through the reaction of Portland cement with sulfur compounds).

The deterioration affecting Ariadne's house wall paintings, produced by salt crystallization, requires the elimination or reduction of the contributions of salt solutions, i.e. the mechanical removal of the mortars used in the past century for the structural consolidation of the paintings. However, since these wall paintings are placed at their original context, in an outdoor archaeological site, the measure to eliminate or reduce pollutant concentrations is not easy to apply as these can come from the adjacent houses or the floor. Among the solutions that can slow the deterioration process we may highlight a control of the evaporation-crystallization cycles through monitoring the environmental parameters and creating barriers to moisture in the walls of the house to prevent moisture by capillary.

Furthermore it is necessary a direct conservative intervention on frescoes, to prevent detachment of paint layers by applying specific restoration methodologies, such as pre-consolidation, salt elimination treatments and consolidation of the layers of color to its support and further protection.

Summarizing, it is important to emphasize the need for regular monitoring of interventions, through a control of the frescoes state of conservation $(45,46)$, the study of the support (47) and the compatibility of restoration materials with the work and environmental contaminants.

\subsection{Photography}

The results obtained with high resolution digital photography, IR photography and infrared false-color photography can be very useful in restoration. With them we get information that often eludes our vision especially if complemented or joined with other techniques like in this work, such as infrared reflectography, multispectral, thermography, etc.

Infrared false-color photography is a useful supplementary technique for the examination and characterization of objects, especially pigment identification (35). Figure 9 is useful for a more thorough explanation of this technique, where we can see more details and a greater definition of the lines and contours that would be essential in a future restoration. 




Figura 9. Comparación de reflectografía de infrarrojos. Esta figura nos permite apreciar sutilezas necesarias (por ejemplo, zona del cuadro negro) a fin de hacer juicios precisos sobre objetos arqueológicos. De izquierda a derecha: fotografía digital RGB, fotografía infrarroja (IR) y fotografía infrarroja de falso color (IR-RG).

Figure 9. Infrared reflectography comparison. This Fig. allows us to appreciate subtleties (e.g. the black square) needed in order to make accurate judgments about archeological objects. From left to right: digital RGB photography, infrared photography (IR) and false-color IR photography (IR-RG).

\section{CONCLUSIONES}

Los estudios desarrollados en este trabajo (estudios ambientales, las mediciones de radiación electromagnética, el estudio de los materiales y fotografía), permitió documentar el estado de conservación de la casa de Ariadna y la evaluación de los procedimientos más convenientes para una conservación preventiva, así como incrementar el conocimiento de los materiales utilizados en su construcción, su proceso pictórico y cuál ha sido el proceso de deterioro, para la discusión de una futura restauración.

Los estudios sugieren que el proceso de deterioro se ha acelerado debido a la cubierta transparente instalada. A continuación, se determinó que la cubierta óptima debe ser opaca y lo más aislada posible y, si es factible, que cubra las paredes y las puertas para impedir la entrada de agua de lluvia y la luz solar y elevar la cubierta un poco para lograr la ventilación de la habitación.

Así, la decisión sobre el cambio de los tejados fue tomada y en 2009-2010 fueron sustituidos. Como consecuencia, la variabilidad de las condiciones ambientales se ha reducido considerablemente y los valores se han aproximado a los óptimos.

El enfoque multidisciplinar ha sido fundamental para lograr el objetivo de este trabajo. El estudio de los materiales y el estudio fotográfico también han demostrado la importancia de controlar las condiciones ambientales a fin de detener el deterioro causado por la cristalización de sales, junto con la aplicación de técnicas específicas

\section{CONCLUSIONS}

The studies developed in this work (environmental study, electromagnetic radiation measurement, the study of materials and photography) allowed documenting the state of conservation of Ariadne's house and evaluating the most convenient procedures for a preventive conservation as well as increasing the knowledge about the materials used in its construction, its pictorial procedure and what has been the process of deterioration for the discussion of a future restoration.

The studies suggest that the deterioration process has been accelerated due to the transparent rooftop used. Then, it was determined that the optimal cover should be opaque and as isolated as possible and, if feasible, covering the walls and the doors to prevent the entry of rain water and sunlight and raising the deck a little to achieve the ventilation of the room.

Therefore the decision on changing the rooftops was taken and within 2009-2010 they were replaced. As consequence, the variability of the environmental conditions has been considerably reduced and the values have approximated to the optimal ones.

The multidisciplinary approach has been fundamental to achieve the goal of this work. The study of materials and the photographic study have also shown the relevance of monitoring the environmental conditions in order to stop the deterioration caused by salts crystallization, together with the application of specific techniques for fixing the 
para la fijación de la policromía, proporcionando conocimiento valioso para una posible restauración en el futuro. Además, estos estudios muestran el actual estado de las pinturas que posiblemente empeorará en el transcurso de los próximos años.

\section{AGRADECIMIENTOS}

Este trabajo fue parcialmente apoyado por el español "Ministerio de Ciencia e Innovación" en los proyectos HAR2010-21944-C02-01 y HAR2010-21944-C02-02. Los autores agradecen a J. Mínguez por sus correcciones gramaticales de inglés. polychrome, providing valuable knowledge for a possible restoration in the future. In addition, these studies reveal the current state of conservation of the frescoes that will get worse over the years.

\section{ACKNOWLEDGEMENTS}

This work was partially supported by the Spanish "Ministerio de Ciencia e Innovación" under projects HAR201021944-C02-01 and HAR2010-21944-C02-02. The authors are grateful to J. Mínguez for his English grammar corrections.

\section{BIBLIOGRAFÍA / BIBLIOGRAPHY}

(1) Pesando, F.: La Casa de Ariadna de Pompeya: redescubrimiento de una domus, in Ribera, A.; Olcina, M.; Ballester, C.; Pompeya bajo Pompeya, Las excavaciones en la Casa de Ariadna, Valencia, Spain (2007).

(2) Pesando, F.: Domus: edilizia privata e società pompeiana fra III e I secolo a.C. "L'Erma" di Bretschneider, Rome (1997).

(3) Kontozova-Deutsch, V.; Cardell, C.; Urosevic, M.; Ruiz-Agudo, E.; Deutsch, F.; Van Grieken, R.: "Characterization of indoor and outdoor atmospheric pollutants impacting architectural monuments: the case of San Jerónimo Monastery (Granada, Spain)", Environ Earth Sci, vol. 63 (2011) pp. 1433-1445, DOI: 10.1007/s12665-010-0657-5.

(4) Arnold, A.; Zehnder, K.: "Monitoring wall paintings affected by soluble salts". In The Conservation of Wall Paintings, 2nd ed.; Cather, S., Ed.; Courtauld Institute of Art and the Getty Conservation Institute: London, UK (1996); pp. 103-136.

(5) La Gennusa, M.; Rizzo, G.; Scaccianoce, G.; Nicoletti, F.: "Control of indoor environments in heritage buildings: Experimental measurements in an old Italian museum and proposal of a methodology", J. Cult. Herit., vol. 6 (2005) pp. 147-155, doi: 10.1016/j. culher.2005.03.001.

(6) Ariño, X.; Saiz-Jiménez, C.: "Deterioration of the Elephant Tomb (Necropolis of Carmona, Seville, Spain)", Int. Biodeter. Biodegr., Vol. 40 (1997) 233-239, doi: 10.1016/S0964-8305(97)00034-6.

(7) Miriello, D.; Barca, D.; Bloise, A.; Ciarallo, A.; Crisci, G.M.; De Rose, T.; Gattuso, C.; Gazineo, F.; La Russa, M.F.: "Characterisation of archaeological mortars from Pompeii (Campania, Italy) and identification of construction phases by compositional data analysis", J. Arch. Sci., vol. 37 (2010), pp. 2207-2223, doi: 10.1016/j.jas.2010.03.019.

(8) Volpin, S.; Appolonia. L.: Le analisi di laboratorio applicate ai beni artistici policromi. Collana i Talenti, Il Prato (1999).

(9) Creagh, D.; Bradley, D.: Radiation in Art and Archeometry. Elsevier, Amsterdam (2000).

(10) Van der Weerd, J.; Van Veen, M.K.; Heeren, R.M.A.; Boon, J.J.: "Identification of pigments in paint cross sections by reflection visible light imaging microspectroscopy". Analytical Chemistry 75 (4) (2003), pp. 716-722.

(11) Nevin, A.; Melia, J.L.; Osticioli, I.; Gautier, G.; Colombini, M.P.: "The identification of copper oxalates in a 16th century Cypriot exterior wall painting using micro FTIR, micro Raman spectroscopy and Gas Chromatography-Mass Spectrometry", J. Cult. Herit. , vol. 9 (2008), pp. 154-161, doi: 10.1016/j.culher.2007.10.002.

(12) Ferro, D.: La microscopia elettronica a scansione per la storia,per l'arte, per la conservazione. Istituto Centrale per la Patologia del Libro, Roma (2007).

(13) Botticelli. G.: Metodologia e Restauro delle Pitture Murali. Edizioni Centro Di, Firenze (1992).

(14) Mora, P.; Mora, L.; Philippot, P.: La conservazione delle pitture murali. Editrice Compositori, Bologna (2002).

(15) Martinez, M.C.I.; Seoane, A.N.; Romani, J.R.V.: "Study of the deterioration of the ancient stone walls of San Antolin de Toques in Gali$\mathrm{cia}$, Spain, and the influence of the substitution of traditional lime mortars", Proceedings of the 19975 th International Conference on Structural Studies, Repairs and Maintenance of Historical Buildings, STREMAH V; San Sebastian, Spain; Code46967. Vol. 3 (1997), pp 221-231.

(16) Augusti. S.: La tecnica del'antica pittura parietale pompeiana. Gaetana Macchiaroli Editore, Nápoles (1950).

(17) Plinio. C. S.: Historia Naturelle. Eds. Capps, E., Rouse, W. N. D., Post, L. A. y Warmington, E. H., in The Loeb Classical libraty. William Heinermann Ltd., Harvard University Press, Cambridge, Mass. (1958-1966).

(18) Vitruvio. M. L.: De Architectura Libri Decem. Edición crítica por S. Ferri. Fratelli Palombi. Roma (1960).

(19) Maltese. C.: Las técnicas artísticas. Ediciones Cátedra, S.A. Madrid (1985).

(20) Genestar, C.; Pons, C.; Más, A.: "Analytical characterisation of ancient mortars from the archaeological Roman city of Pollentia (Balearic Islands, Spain)". Analytica Chimica Acta 557 (2006), pp. 373-379. 
(21) Castriota, M.; Cosco, V.; Barone, T.; De Santo, G.; Carafa, P.; Cazzanelli, E.: "Micro-Raman characterizations of Pompei'smortars". Journal of Raman Spectroscopy 39 (2) (2008), pp. 295-301.

(22) Maguregui, M.; Knuutinen, U.; Castro, K.; Madariaga, J.M.: "Raman spectroscopy as a tool to diagnose the impact and conservation stateof Pompeian second and fourth style wall paintings exposed to diverseenvironments (House of Marcus Lucretius)". Journal of Raman Spectroscopy 41 (11) (2010), pp. 1400-1409.

(23) Durán, A.; Pérez-Maqueda, L.A.; Poyato, J.; Pérez-Rodríguez, J.L.: "A thermal study approach to roman age wall painting mortars". J Therm Anal Calorim 99 (3) (2010), pp. 803-809.

(24) Pérez, C.; Ferrazza, L.; Doménech, M.; Sarrió, F.; Ribera, A.: Las pinturas murales de la Casa de Ariadna en Pompeya: Un ejemplo de estudio e investigaciones científicas aplicados en el proyecto de conservación y restauración, La Ciencia y el Arte II, Ciencias experimentales y conservación del Patrimonio Histórico, Ministerio de Cultura, Madrid, Spain (2010).

(25) Andreas; Kon, Z.: "Monitoring wall paintings affected by soluble salts". The conservation of wall paintings: proceedings of a symposium organized by the Courtald Institute of Art and the Getty Conservation Institute, London, july 13-16 (1987).

(26) Peña-Poza, J., Conde, J.F., Palomar, T., Agua, F., García-Heras, M., Villegas, M.A.: "Environmental evaluation of the holdings at the CCHS-CSIC Tomás Navarro Tomás library", Revista Espanola de Documentacion Cientifica, vol. 34 (2011), pp. 65-78, doi: 10.3989/redc.2011.1.774.

(27) Zarzo, M.; Fernández-Navajas, A.; García-Diego, F.: "Long-term monitoring of fresco paintings in the cathedral of Valencia (Spain) through humidity and temperature sensors in various locations for preventive conservation", Sensors, vol. 9 (2011), pp. 8685-8710, doi: 10.3390/s110908685.

(28) Grinzato, E.; Bressan, C.; Marinetti, S.; Bison, P.G.; Bonacina, C.: "Monitoring of the Scrovegni Chapel by IR thermography: Giotto at infrared", Infr. Phys. Tech., vol. 43 (2002), pp. 165-169, doi: 10.1016/S1350-4495(02)00136-6.

(29) Palombi, L.; Cecchi, G.; Lognoli, D.; Raimondi, V.; Masotti, L.: "A fluorescence imaging lidar for the control of cultural heritage", Proceedings of SPIE - The International Society for Optical Engineering, vol. 6750 (2007), art. no. 675002, doi: 10.1117/12.739680.

(30) Bonizzoni, L.; Caglio, S.; Galli, A.; Poldi, G.: "Comparison of three portable EDXRF spectrometers for pigment characterization", X-Ray Spectrom., vol. 39 (2010) pp. 233-242, doi: 10.1002/xrs.1253.

(31) López, M.C.; Medina, V.J.; Adroher, A.M.; García, A.: "Estudio de materiales y técnica de ejecución de los restos de pintura mural romana hallados en una excavación arqueológica en Guadix (Granada)", Espacio, Tiempo y Forma, Serie I, Prehistoria y Arqueología, vol. 13 (2000), pp. 253-278.

(32) Edreira, M.C.; Feliu, M.J.; Fernández-Lorenzo, C.; Martín, J.: "Roman wall painting characterization from Cripta del Museo and Alcazaba in Mérida (Spain): chromatic, energy dispersive X-ray fluorescence spectroscopic, X-ray diffraction and Fourier transform infrared spectroscopic analysis", Analyt. Chim. Acta, vol. 434 Issue 2 (2001), pp. 331-345, doi: 10.1016/S00032670(01)00847-9.

(33) Schirripa, G.: "Virtual restoration: detection and removal of craquelure in digitized image of old paintings", Proceedings of SPIE - The International Society for Optical Engineering 8084, 2011, art. no. 80840B, doi: 10.1117/12.888299.

(34) Dellepiane, M.; Venturi, A.; Scopigno, R.: "Image guided reconstruction of un-sampled data: a filling technique for cultural Heritage models", Int. Journal of Computer Vision, Vol. 94 (2011) pp. 2-11, doi: 10.1007/s11263-010-0382-2.

(35) Moon, T.; Schilling, M.R.; Thirkettle, S.: "A note on the use of false-color infrared photography in conservation", Stud. Conservat., vol. 37 (1992), pp. 42-52.

(36) Klein, M.E.; Aalderink, B.J.; Padoan, R.; De Bruin, G.; Steemers, T.A.G.: "Quantitative hyperspectral reflectance imagining", Sensors, vol. 8 (2008) pp. 5576-5618, doi: 10.3390/s8095576.

(37) Veniale, F.; M.; Setti, M.; Lodola, S.: "Diagnosing stone decay in built heritage. Facts and perspectives" Mater. Constr., vol. 58, n0289 (2008), doi: 10.3989/mc.2008.v58.i289-290.85.

(38) Liu, B.; Chen, X.; Fang, D.; Perrone, A.; Pispas, A.; Vainos, N.A.: "Environmental monitoring by thin film nanocomposite sensors for cultural heritage preservation", Jour. Alloys Comp., vol. 504 (2010) S405-S409, doi: 10.1016/j.jallcom.2010.02.147.

(39) UNI 10829. Works of Art of Historical Importance. Ambient Conditions for the Conservation. Measurement and Analysis; UNI Ente Nazionale Italiano di Unificazione: Milano, Italy, 1999.

(40) ASMETEC. Meteolite UV 400 description of UV-filter-sleeves UV-400. www.asmetec.de (2011).

(41) Gurioli, L.; Cioni, R.; Sbrana, A.; Zanella, E.: "Transport and deposition of pyroclastic density currents over an inhabitated area: the deposits of the AD 79 eruption of Vesuvius at Herculaneum, Italy". Sedimentology, 49 (5) (2002), pp. 929-953.

(42) Selim, A.: I colori pompeiani, Rome, 1967.

(43) Corpora, H.; Quaresima, R.: Malte storiche e da restauro: stato dell 'arte, considerazioni e prospettive alla luce della normativa esistente. Edizioni Il prato, Padova (2007).

(44) Baglioni, P.; Bitossi, G.; Fratini, F.; Rescic, S.; Dei, L.: "Salt crystallization in porous materials: physicochemical aspects and effects of antiscaling additives". Proceedings: Science and technology for cultural heritage - Atti II Convegno naz. Chmica dei beni culturali della Società Chimica Italiana - Torino 23-26 giugno 2003- Istituti editoriali e poligrafici internazionali MMIV. 
(45) Castellano, A.; Cesareo, R.; Buccolieri, G.; Donativi, M.; Palama, F.; Quarta, S.; De Nunzio, G.; Brunetti, A.; Marabelli, M.; Santamaria, U.: "Detection of detachments and inhomogeneities in frescos by Compton scattering", Nucl Instrum Meth A, vol. 234 (2005), pp. 548-554, doi: 10.1016/j.nimb.2005.02.012.

(46) Zehnder. K.: "Long term monitoring of wall painting affected by soluble salts". Environmental Geology 52 (2) (2007), pp. 395-409.

(47) García-Diego, F. J.; María Bravo, J.; Pérez-Miralles, J.; Estrada, H.; Fernández-Navajas, A.: "Development of a low-cost airborne ultrasound sensor for the detection of brick joints behind a wall painting", Sensors, vol. 12 (2012), pp. 1299-1311, doi: $10.3390 /$ s120201299. 